Formatif: Jurnal Ilmiah Pendidikan MIPA

Vol. 9, No. 1, Maret 2019, pp. 1-10

p-ISSN: 2088-351X

e-ISSN: 2502-5457

DOI: http://dx.doi.org/10.30998/formatif.v9i1.2773

\title{
Development of Student Work Sheets Based on Contextual Learning to Facilitate Mathematic Concept Understanding Skill of Junior High School Student $7^{\text {th }}$ Grade at Triangle Material
}

\author{
Pengembangan Lembar Kegiatan Siswa Berbasis Pembelajaran Kontekstual \\ untuk Memfasilitasi Kemampuan Pemahaman Konsep Matematis \\ Siswa Kelas VII SMP/MTS pada Bahasan Segitiga
}

\author{
Citra Murti Anggraini (*) \\ Universitas PGRI Yogyakarta \\ Jl. PGRI I Sonosewu No. 117 Yogyakarta \\ Kristina Warniasih \\ Universitas PGRI Yogyakarta \\ Jl. PGRI I Sonosewu No. 117 Yogyakarta \\ Padrul Jana \\ Universitas PGRI Yogyakarta \\ Jl. PGRI I Sonosewu No. 117 Yogyakarta
}

$\begin{array}{ll}\text { Received: } & \text { August 23, } 2018 \\ \text { Revised: } & \text { December 5, } 2018 \\ \text { Accepted: } & \text { December 7, } 2018\end{array}$

\begin{abstract}
The research purpose was to produce learning material as the quality of Student Work Sheets based on contextual learning to facilitate Mathematics concept understanding skill of Junior High School student 7th Grade at triangle material and to describe the quality of Student Work Sheets that has a valid, simple and effective qualification. Student Work Sheets development based on Ministry of Education development model that adapted from Borg and Gall procedure development through some steps: (1) doing product development analysis, (2) developing beginning product, (3) expert's validation and revision, (4) small-scale field test and product revision, and (5) significant scale field test and last product. Student Work Sheets quality described based on the marking result of material expert, media expert, and mathematics teacher for the validation aspect, student respond questionnaire and observation sheets of learning application for simplicity aspect, also a post-test question for affectivity aspect. The research result showed that the quality of Student Work Sheets product in validation aspect fulfill good and very good criteria based on the mark from a material expert, media expert, and assessor with the average score for each aspect.

Keywords: Student work sheets, contextual learning, mathematic concept understanding skill
\end{abstract}

(*) Corresponding Author: $\quad$ citramanggraini@gmail.com -082138069859

How to Cite: Anggraini, C.M., Warniasih, K., \& Jana, P. (2019). Development of student work sheets based on contextual learning to facilitate mathematic concept understanding skill of junior high school student $7^{\text {th }}$ grade at triangle material. Formatif: Jurnal Ilmiah Pendidikan MIPA, 9 (1): 1-10. http://dx.doi.org/10.30998/formatif.v9i1.2773 
Formatif: Jurnal Ilmiah Pendidikan MIPA

Vol. 9, No. 1, Maret 2019, pp. 1-10

p-ISSN: 2088-351X

e-ISSN: 2502-5457

DOI: http://dx.doi.org/10.30998/formatif.v9i1.2773

\section{PENDAHULUAN}

Matematika merupakan suatu pengetahuan yang digunakan di setiap sisi kehidupan. Dalam kehidupan nyata, matematika dapat digunakan untuk menyelesaikan permasalahan yang dihadapi sehari-hari. Matematika juga merupakan sumber untuk ilmu pengetahuan lain. Oleh karena itu, matematika sangatlah penting dipelajari di setiap jenjang pendidikan serta dalam kehidupan sehari-hari.

Perkembangan pembelajaran matematika di Indonesia masih memprihatinkan. Rendahnya kualitas pembelajaran matematika di Indonesia salah satunya bisa dilihat dari data TIMSS (Trends in International Mathematics and Science Study) 2015, capaian siswa Indonesia masih berada di tingkat bawah, baik dilihat secara keseluruhan maupun dirinci per domain konten dan kognitif. Proses pembelajaran matematika dikatakan berhasil dapat dilihat dari keberhasilan siswa yang mengikuti pembelajaran tersebut (Layn, 2018). Siswa Indonesia masih menguasai soal-soal yang bersifat teratur, tidak berubah-ubah, algoritma sederhana, dan mengukur pengetahuan terhadap fakta yang berkonteks keseharian. Selain itu masih banyaknya siswa yang beranggapan bahwa pelajaran Matematika adalah pelajaran yang sukar dan membutuhkan konsentrasi yang tinggi (Yuliyani \& Handayani, 2017). Hasil TIMSS 2015 menunjukkan bahwa Indonesia masih berada di peringkat 45 dari 50 negara. TIMSS adalah studi internasional yang mengukur kemampuan siswa di bidang matematika dan sains.

Tujuan pembelajaran matematika menurut Peraturan Menteri Pendidikan dan Kebudayaan Nomor 58 tahun 2015 tentang Penyelenggaraan Ujian Sekolah/Madrasah atau Bentuk lain yang Sederajat adalah memahami konsep matematika, menjelaskan keterkaitan antarkonsep dan mengaplikasikan konsep secara luwes, akurat, efisien, dan tepat dalam pemecahan masalah. Kilpatrick (Afrilianto, 2012) berpendapat pemahaman konsep adalah kemampuan dalam memahami konsep, operasi, dan relasi dalam matematika. Belajar matematika disertai dengan pemahaman konsep diperlukan untuk memungkinkan siswa belajar secara bermakna. Bagi siswa yang belum memahami konsep akan sangat sulit untuk menuju ke proses pembelajaran yang lebih tinggi, sehingga siswa akan menganggap matematika merupakan pelajaran yang sulit.

Pemahaman konsep matematika merupakan salah satu hal yang perlu diperhatikan, karena dengan penguasaan konsep akan memudahkan siswa dalam belajar matematika. Siswa dikatakan memahami konsep jika mampu mendefinisikan konsep, memberi contoh dan bukan contoh, mengidentifikasi konsep, serta menggunakan matematika dalam konteks di luar matematika menurut Kesumawati (Istikhomah \& Jana, 2018). Dalam mempelajari konsep matematika tersebut harus bersesuaian dan berkesinambungan, karena antara konsep matematika yang satu dengan yang lain saling bersangkutan. Hal ini sejalan dengan Handayani (2016) yang mengemukakan belajar matematika dengan disertai pemahaman merupakan komponen terpenting dari kemampuan bersama dengan kemampuan pengetahuan berdasarkan kenyataan dan sesuai dengan prosedur. Adapun indikator pemahaman konsep menurut kurikulum 2006 (Arifah \& Saefudin, 2017) yaitu: (1) Menyatakan ulang sebuah konsep; (2) Mengklasifikasi objek-objek menurut sifat-sifat tertentu (sesuai dengan konsepnya); (3) Memberikan contoh dan bukan contoh dari suatu konsep; (4) Menyajikan konsep dalam berbagai bentuk representasi matematis; (5) Mengembangkan syarat perlu atau syarat cukup dari suatu konsep; (6) Menggunakan dan memanfaatkan serta memilih prosedur atau operasi tertentu; (7) Mengaplikasikan konsep atau algoritma dalam pemecahan masalah.

Mengingat pentingnya proses pembelajaran matematika, maka pendidik dituntut untuk mampu menciptakan suasana belajar matematika yang mudah dan menyenangkan sehingga proses belajar menjadi bermakna bagi siswa. Salah satu cara untuk menjadikan 
Formatif: Jurnal Ilmiah Pendidikan MIPA

Vol. 9, No. 1, Maret 2019, pp. 1-10

p-ISSN: 2088-351X

e-ISSN: 2502-5457

DOI: http://dx.doi.org/10.30998/formatif.v9i1.2773

suatu pembelajaran bermakna bagi siswa, guru dapat menggunakan berbagai metode dan perangkat pembelajaran dengan melibatkan siswa secara penuh serta sesuai dengan kondisi siswa dan karakter dari materi yang diajarkan. Penggunaan pengembangan media pembelajaran dan bahan ajar yang digunakan oleh guru merupakan salah satu faktor penting dalam mencapai hal tersebut. Bahan ajar yang dapat digunakan untuk mengatasi permasalahan di atas yaitu Lembar Kegiatan Siswa (LKS). Diharapkan, LKS dapat menunjang aktivitas pembelajaran di sekolah dalam rangka meningkatkan pemahaman konsep matematika. Karena berdasarkan analisis prapenelitian, diketahui pemahaman konsep siswa melalui beberapa indikator masih rendah.

Lembar kegiatan siswa (student work sheet) adalah sekumpulan kegiatan mendasar yang harus diselesaikan oleh peserta didik untuk memaksimalkan pemahaman dalam upaya pembentukan kemampuan dasar sesuai indikator pencapaian yang akan ditempuh menurut Trianto (Saraswati \& Nuryani, 2018). Penelitian yang dilakukan oleh Saraswati dan Nuryani juga mengembangkan Lembar Kegiatan Siswa berdasarkan model pembelajaran Guided Discovery yang berkualitas dari segi valid, praktis, dan efektif. Hanya saja, LKS yang dikembangkan masih berfokus pada Guided Discovery belum secara spesifik dapat memfasilitasi kemampuan tertentu. Sehingga akan sangat menarik apabila pengembangan LKS yang memenuhi semua unsur valid, praktis, dan efektif serta berdasar pada model pembelajaran dan fokus kemampuan tertentu. Pengembangan Lembar Kerja Siswa berbasis pendekatan inkuiri terbimbing dalam pembelajaran kooperatif juga dikembangkan oleh Astuti \& Setiawan (2013). Hanya saja, kelemahannya masih berpusat pada pendekatan belum mampu memfasilitasi kemampuan tertentu secara spesifik. Lembar kegiatan biasanya berupa petunjuk atau langkah-langkah untuk menyelesaikan suatu tugas (Sungkono, 2009). Menurut Widjajanti (Gazali, 2016), LKS mempunyai beberapa fungsi di antaranya: (1) Sebagai alternatif bagi guru untuk mengarahkan pengajaran atau memperkenalkan suatu kegiatan tertentu sebagai kegiatan belajar mengajar; (2) Dapat digunakan untuk mempercepat proses pengajaran dan menghemat waktu penyajian suatu topik; (3) Membantu siswa dapat lebih aktif dalam proses belajar mengajar; (4) Dapat membangkitkan minat siswa jika LKS disusun secara rapi, sistematis, mudah dipahami oleh siswa sehingga menarik perhatian siswa; (5) Dapat menumbuhkan kepercayaan diri dan meningkatkan rasa ingin tahu siswa; (6) Dapat meningkatkan kemampuan siswa dalam memecahkan masalah.

Belajar matematika akan menjadi lebih mudah jika dihubungkan dengan masalah kehidupan nyata. Dengan dihubungkannya pada kehidupan nyata, pasti siswa nantinya akan lebih mudah dalam mempelajari konsep matematika. Dengan dihubungkannya pada kehidupan nyata, pasti siswa nantinya akan lebih mudah dalam mempelajari konsep matematika. Salah satu pendekatan pembelajaran yang dapat membatu mengaitkan materi pembelajaran dengan dunia nyata adalah pembelajaran kontekstual. Pembelajaran kontekstual dapat menumbuhkan kesadaran terhadap matematika sebagai ilmu yang terkait dengan kehidupan sehari-hari (Karim, 2017). Sejalan dengan pendapat yang dikemukakan Udin (Rahayu, Rasna, \& Artawan, 2013) menyatakan pembelajaran kontekstual adalah suatu pendekatan pembelajaran yang menekankan kepada proses keterlibatan siswa secara penuh untuk dapat menemukan materi yang dipelajari dan menghubungkannya dengan situasi kehidupan nyata sehingga mendorong siswa untuk dapat menerapkannya dalam kehidupan mereka. Dalam pembelajaran kontekstual melibatkan tujuh komponen utama (Suhana, 2014), yakni: (1) konstruktivisme (constructivism), (2) bertanya (questioning), (3) menemukan (inquiry), (4) masyarakat belajar (learning community), (5) pemodelan (modeling), (6) refleksi (reflection), dan (7) penilaian sebenarnya (authentic assessment). Selain tujuh komponen tersebut, dalam penggunaan pembelajaran kontekstual, ada tiga hal yang perlu diperhatikan yaitu 


\section{Formatif: Jurnal Ilmiah Pendidikan MIPA}

Vol. 9, No. 1, Maret 2019, pp. 1-10

p-ISSN: 2088-351X

e-ISSN: 2502-5457

DOI: http://dx.doi.org/10.30998/formatif.v9i1.2773

pembelajaran ini menekankan kepada proses keterlibatan siswa untuk menemukan pengetahuan, mendorong agar siswa dapat menemukan hubungan antara materi yang dipelajari dengan kehidupan nyata, dan mendorong siswa untuk dapat menerapkan dalam kehidupan menurut Ramdani (Artikasari \& Saefudin, 2017).

\section{METODE}

Penelitian ini digolongkan pada penelitian dan pengembangan (research and development). Metode penelitian dan pengembangan adalah metode penelitian yang digunakan untuk menghasilkan produk tertentu dan menguji keefektifan produk tersebut (Sugiyono, 2016). Langkah-langkah pengembangan bahan ajar yang digunakan berdasarkan model pengembangan Depdiknas (Puslitjaknov, 2008) yang diadaptasi dari prosedur pengembangan Borg dan Gall melalui tahap: (1) Melakukan analisis produk yang dikembangkan; (2) Mengembangkan produk awal; (3) Validasi ahli dan revisi; (4) Uji coba lapangan skala kecil dan revisi produk; (5) Uji coba lapangan skala besar dan produk akhir. Pada tahap analisis produk yang dikembangkan, terdapat beberapa kegiatan di antaranya analisis kebutuhan siswa, analisis karakteristik siswa, analisis kurikulum, dan melakukan studi pustaka. Pada tahap mengembangkan produk awal, hasil analisis digunakan untuk acuan dalam penyusunan suatu kerangka isi bahan ajar pembelajaran. Tahap selanjutnya, validasi ahli dan revisi, dilakukan validasi instrumen penelitian dan produk draf 1. Tahap keempat, yaitu uji coba lapangan skala kecil dan revisi produk, dilakukan untuk mendapatkan informasi tentang aspek keterbacaan pada LKS serta kelancaran atau hambatan yang sekiranya akan ditemukan oleh siswa ketika menggunakan LKS dalam pembelajaran. Terakhir, uji coba lapangan skala besar dan produk akhir, produk diujicobakan kepada siswa satu kelas dan diperoleh produk akhir. Produk akhir yang dimaksud adalah LKS yang dikembangkan berbasis pembelajaran kontekstual untuk memfasilitasi kemampuan pemahaman konsep matematis siswa kelas VII SMP/MTs pada bahasan segitiga.

\section{HASIL DAN PEMBAHASAN}

\section{Hasil}

Hasil penelitian pada tahap pertama yaitu analisis produk yang dikembangkan. Pada tahap ini terdiri dari analisis kebutuhan siswa, analisis karakteristik siswa, dan analisis kurikulum. Pada tahap analisis kebutuhan siswa diperoleh hasil wawancara dengan guru bahwa bahan ajar yang ada umumnya hanya untuk materi tertentu saja, belum mencukupi kebutuhan pembelajaran dari segi materi yang disajikan secara singkat, kurangnya ruang bagi siswa untuk mengonstruksi pengetahuannya sendiri. Hal tersebut kurang efektif digunakan dalam proses pembelajaran. Pada tahap analisis karakteristik siswa dengan wawancara dan dilanjutkan dengan tes kemampuan pemahaman konsep matematika siswa untuk kelas VII yang telah dilaksanakan pada kegiatan studi pendahuluan di SMPN 12 Yogyakarta.

Hasil analisis kurikulum yang dilakukan peneliti menunjukkan bahwa SMPN 12 Yogyakarta menggunakan Kurikulum 2013. Kompetensi dasar (KD) yang berkaitan dengan materi segitiga dari dua kompetensi inti (KI). Kompetensi inti yang dimaksud adalah KI 3 dan 4. Dari kedua poin KD dirumuskan indikator-indikator pencapaian kompetensi siswa. Indikator pencapaian tersebut nantinya akan digunakan sebagai dasar 


\section{Formatif: Jurnal Ilmiah Pendidikan MIPA}

Vol. 9, No. 1, Maret 2019, pp. 1-10

p-ISSN: 2088-351X

e-ISSN: 2502-5457

DOI: http://dx.doi.org/10.30998/formatif.v9i1.2773

dalam pengembangan LKS berbasis pembelajaran kontekstual pada materi segitiga. Adapun rumusan indikator pencapaian kompetensi tersebut adalah: (1) Menjelaskan pengertian dan jenis segitiga; (2) Menjelaskan sifat segitiga; (3) Menentukan sudut dalam dan luar segitiga; (4) Menurunkan rumus untuk menentukan keliling segitiga; (5) Menurunkan rumus untuk menentukan luas segitiga; (6) Menyelesaikan masalah yang berkaitan dengan pengertian, jenis, dan sifat segitiga; (7) Menyelesaikan masalah yang berkaitan dengan keliling segitiga; (8) Menyelesaikan masalah yang berkaitan dengan luas segitiga.

Hasil penelitian pada tahap kedua yaitu mengembangkan produk awal. Langkahlangkah yang dilakukan pada tahap ini adalah: (1) Menyusun peta kebutuhan LKS matematika berbasis pembelajaran kontekstual; (2) Mengumpulkan materi pendukung pokok bahasan segitiga; (3) Menyusun kerangka struktur LKS matematika; (4) Penyusunan draf buku guru; (5) Membuat desain awal produk LKS; (6) Membuat LKS matematika berbasis kontekstual untuk siswa SMP/MTs; (7) Menyusun instrumen penilaian LKS Matematika berbasis kontekstual oleh ahli dan guru; (8) Menyusun angket respons siswa dan lembar observasi keterlaksanaan pembelajaran; (9) Menyusun instrumen post test untuk siswa kelas VII yang menggunakan LKS Matematika berbasis pembelajaran kontekstual.

Tahap ketiga yaitu validasi ahli dan revisi. Setelah instrumen penilaian LKS, angket respons siswa, instrumen post test, dan produk LKS disusun serta dikonsultasikan dengan dosen pembimbing, langkah selanjutnya adalah instrumen dan produk LKS divalidasi kepada ahli materi dan media. Validasi dilakukan menjadi dua bagian, yaitu pertama memvalidasi instrumen penilaian yang meliputi instrumen penilaian LKS oleh ahli materi dan media serta penilai yaitu guru, lembar observasi keterlaksanaan pembelajaran, angket respons siswa, dan instrumen post test. Kedua memvalidasi produk, yaitu LKS.

Tahap keempat yaitu uji coba lapangan skala kecil dan revisi produk. Uji coba lapangan skala kecil bertujuan untuk mendapatkan informasi tentang aspek keterbacaan pada LKS dan kelancaran atau hambatan yang sekiranya akan ditemukan oleh siswa ketika menggunakan LKS dalam pembelajaran. Subjek uji coba lapangan skala kecil ini adalah enam siswa kelas VIII SMPN 12 Yogyakarta. Pengambilan sampel ini didasarkan pada syarat didaktik penyusunan LKS baik, yaitu LKS dapat digunakan baik oleh siswa yang lamban, sedang, dan pandai. Kritik atau saran yang diperoleh berdasarkan hasil uji coba lapangan skala kecil digunakan untuk melakukan revisi atau perbaikan terhadap produk LKS sehingga didapatkan LKS matematika berbasis kontekstual yang lebih baik lagi. Selanjutnya tahap kelima yaitu uji coba lapangan skala besar dan produk. Uji coba lapangan skala besar dilaksanakan pada seluruh siswa kelas VII E SMPN 12 Yogyakarta dengan jumlah siswa sebanyak 32 anak. Uji coba lapangan ini dilakukan melalui proses pembelajaran matematika dengan menggunakan LKS Matematika berbasis pembelajaran kontekstual pada materi segitiga. Pembelajaran dengan LKS dilaksanakan sebanyak dua kali pertemuan dan satu pertemuan untuk post test. Pemberian post test untuk melihat sejauh mana kemajuan yang telah dicapai siswa pada pembelajaran dengan LKS (Jana, 2018).

Kualitas LKS dilihat dari kriteria kevalidan, kepraktisan, dan keefektifan dengan hasil seperti terlihat dalam tabel 1-tabel 6. 
Formatif: Jurnal Ilmiah Pendidikan MIPA

Vol. 9, No. 1, Maret 2019, pp. 1-10

p-ISSN: 2088-351X

e-ISSN: 2502-5457

DOI: http://dx.doi.org/10.30998/formatif.v9i1.2773

Tabel 1. Data Hasil Penilaian LKS oleh Ahli Materi

\begin{tabular}{clcc}
\hline No. & \multicolumn{1}{c}{ Aspek yang dinilai } & Skor rata-rata & Kriteria \\
\hline 1. & Penyajian & 4,0 & Baik \\
2. & Isi & 4,3 & Sangat Baik \\
3. & Basis Pembelajaran Kontekstual & 4,3 & Sangat Baik \\
4. & Memfasilitasi Kemampuan & 4,1 & Baik \\
& Pemahaman Konsep & & \\
5. & Bahasa $\quad$ Total Skor Rata-rata & $\mathbf{4 , 0}$ & Baik \\
\multicolumn{2}{r}{} & & Baik \\
\hline
\end{tabular}

Tabel 2. Data Hasil Penilaian LKS oleh Ahli Media

\begin{tabular}{clcc}
\hline No. & \multicolumn{1}{c}{ Aspek yang dinilai } & Skor rata-rata & Kriteria \\
\hline 1. & Kesederhanaan & 4,3 & Sangat Baik \\
2. & Keterpaduan & 4,0 & Baik \\
3. & Penekanan & 4,5 & Sangat Baik \\
4. & Keseimbangan & 4,0 & Baik \\
5. & Bentuk & 5,0 & Sangat Baik \\
6. & Warna & 4,0 & Baik \\
& Total Skor Rata-rata & $\mathbf{4 , 3 1}$ & Sangat Baik \\
\hline
\end{tabular}

Tabel 3. Data Hasil Penilaian LKS oleh Guru

\begin{tabular}{clcc}
\hline No. & \multicolumn{1}{c}{ Aspek yang dinilai } & Skor rata-rata & Kriteria \\
\hline 1. & Isi & 4,3 & Sangat Baik \\
2. & Kebahasaan & 4,4 & Sangat Baik \\
3. & Penyajian & 4,3 & Sangat Baik \\
4. & Kontekstual & 4,0 & Baik \\
& Total Skor Rata-rata & $\mathbf{4 , 2 3}$ & Sangat Baik \\
\hline
\end{tabular}

Tabel 4. Data Hasil Angket Respons Siswa terhadap LKS

\begin{tabular}{lcc}
\hline \multicolumn{1}{c}{ Aspek } & Rata-rata & Kriteria \\
\hline Kelayakan isi & 3,52 & Baik \\
Penyajian materi & 3,54 & Baik \\
Kebahasaan & 3,71 & Baik \\
Kegrafikan & 3,52 & Baik \\
Penggunaan LKS dalam pembelajaran & 3,56 & Baik \\
Rata-rata keseluruhan & $\mathbf{3 , 5 5}$ & Baik \\
\hline
\end{tabular}

Tabel 5. Data Hasil Observasi Keterlaksanaan Pembelajaran

\begin{tabular}{ccc}
\hline Pertemuan & Keterlibatan $\mathbf{( \% )}$ & Kriteria \\
\hline 1 & 96,55 & Sangat Baik \\
2 & 90,80 & Sangat Baik \\
\% Keterlibatan Total & $\mathbf{9 3 , 6 8}$ & Sangat Baik \\
\hline
\end{tabular}

Tabel 6. Data Hasil Perhitungan Post Test

\begin{tabular}{lc}
\hline Total nilai & 2533,33 \\
Jumlah siswa & 32 \\
Rata-rata nilai & 79,17 \\
Banyaknya siswa yang tuntas & 22 \\
Banyaknya siswa yang tidak tuntas & 10 \\
Persentase Ketuntasan Klasikal & $69 \%$ \\
\hline
\end{tabular}


Formatif: Jurnal Ilmiah Pendidikan MIPA

Vol. 9, No. 1, Maret 2019, pp. 1-10

p-ISSN: 2088-351X

e-ISSN: 2502-5457

DOI: http://dx.doi.org/10.30998/formatif.v9i1.2773

Untuk menguji signifikansinya, maka perlu dilakukan uji t one sample. Hasil uji t satu sampel (One-T sample) diperoleh $t_{\text {hitung }}=2,30$ dan $t_{\text {tabel }}=1,695$ dapat ditarik kesimpulan bahwa $t_{\text {hitung }} \geq t_{\text {tabel }}$ artinya LKS dengan pembelajaran kontekstual efektif dan signifikan ditinjau dari kemampuan pemahaman konsep matematis siswa. Analisis uji t satu sampel dapat dilihat pada lampiran. Berdasarkan hasil tersebut maka LKS dengan pembelajaran kontekstual memenuhi kriteria keefektifan.

\section{Pembahasan}

Tujuan penelitian ini adalah untuk mengembangkan Lembar Kegiatan Siswa (LKS) berbasis pembelajaran kontekstual untuk memfasilitasi kemampuan pemahaman konsep siswa kelas VII SMP/MTs. Kualitas LKS yang dikembangkan dalam penelitian ini dideskripsikan dari tiga aspek yaitu aspek kevalidan, kepraktisan, dan keefektifan. Berdasarkan deskripsi hasil penelitian yang telah diuraikan sebelumnya, langkah-langkah pengembangan bahan ajar yang digunakan berdasarkan model pengembangan Depdiknas yang diadaptasi dari prosedur pengembangan Borg dan Gall (Puslitjaknov, 2008) melalui tahap: (1) Melakukan analisis produk yang dikembangkan; (2) Mengembangkan produk awal; (3) Validasi ahli dan revisi; (4) Uji coba lapangan skala kecil dan revisi produk; (5) Uji coba lapangan skala besar dan produk akhir.

Perbedaan mendasar dari pengembangan LKS yang disusun selain diuji kualitas dari tiga aspek, yaitu fokus kepada pembelajaran kontekstual dan dikembangkan dalam rangka memfasilitasi kemampuan konsep matematis. Secara keseluruhan LKS yang dikembangkan diupayakan pembelajaran dengan pendekatan kontekstual dan isinya dikembangkan sesuai untuk mengukur pemahaman konsep siswa. Kemudian LKS yang spesifik tersebut diuji aspek kevalidan, kepraktisan, dan keefektifan.

Adapun materi yang dikembangkan dalam LKS adalah materi segitiga dengan kompetensi dasar yang harus diraih yaitu 3.11 Mengaitkan rumus keliling dan luas untuk berbagai jenis segiempat (persegi, persegi panjang, belah ketupat, jajaran genjang, trapesium, dan layang-layang) dan segitiga, juga 4.11 Menyelesaikan masalah kontekstual yang berkaitan dengan luas dan keliling segiempat (persegi, persegi panjang, belah ketupat, jajaran genjang, trapesium, dan layang-layang) dan segitiga.

LKS dinyatakan valid karena telah memenuhi kaidah penyusunan lembar kegiatan siswa. Penilaian kedua ahli yaitu ahli materi dan ahli media juga menyatakan kevalidan LKS baik secara materi maupun secara media. Seperti yang telah dijelaskan pada hasil penelitian, aspek kevalidan LKS yang dinilai dari ahli materi, ahli media, dan guru memberikan skor rata-rata 4,19; 4,31; dan 4,23 yang berkategori baik (kriteria valid). LKS dinyatakan praktis karena memberikan kemudahan dan kebermanfaatan. Aspek kemudahan dan kebermanfaatan diperkuat oleh pendapat atau respons dari pengguna LKS. Hasil angket respons siswa memberikan skor 3,55 yang berkategori baik (kriteria praktis). LKS dinyatakan efektif karena dapat memfasilitasi proses belajar dalam rangka menuju tujuan yang diharapkan dan memberikan hasil yang baik. Seperti yang telah dijelaskan sebelumnya, LKS memfasilitasi proses belajar dengan baik. Selain itu, penelitian ini menitikberatkan pada kemampuan pemahaman konsep.

Keefektifan LKS yang dikembangkan dapat dilihat dari banyaknya siswa yang tuntas dalam post test kemampuan pemahaman konsep. Banyak siswa yang tuntas yaitu 22 orang dan 10 orang lainnya belum tuntas. Dengan demikian siswa yang menggunakan LKS, 69\% tuntas dalam tes kemampuan pemahaman konsep dan LKS memenuhi kualifikasi baik. Oleh karena itu LKS dapat dinyatakan efektif menurut Widoyoko (2016). Pembelajaran kontekstual dapat memfasilitasi pemahaman konsep siswa dalam mengaitkan materi pembelajaran dengan kehidupan sehari-hari. Hal ini sesuai bahwa 


\section{Formatif: Jurnal Ilmiah Pendidikan MIPA}

Vol. 9, No. 1, Maret 2019, pp. 1-10

p-ISSN: 2088-351X

e-ISSN: 2502-5457

DOI: http://dx.doi.org/10.30998/formatif.v9i1.2773

pembelajaran kontekstual adalah suatu konsep mengajar dan belajar yang membantu guru mengaitkan antara materi pembelajaran dengan situasi dunia nyata siswa dan mendorong siswa membentuk hubungan antara pengetahuan yang dimilikinya dengan penerapannya dalam kehidupan nyata mereka sehari-hari (Rahayu, Rasna, \& Artawan, 2013).

Berdasarkan uraian di atas dapat disimpulkan bahwa lembar kegiatan siswa (LKS) berbasis pembelajaran kontekstual untuk memfasilitasi kemampuan pemahaman konsep matematis siswa kelas VII SMP/MTs telah dikembangkan sesuai dengan teoriteorinya dan memenuhi kualifikasi valid, praktis, dan efektif.

\section{PENUTUP}

Hasil penelitian menunjukkan bahwa LKS matematika berbasis pembelajaran kontekstual telah memenuhi kriteria kelayakan yang meliputi valid, efektif, dan praktis. Valid berdasarkan penilaian dari ahli yang menunjukkan bahwa kualitas LKS termasuk: (1) Kategori baik menurut ahli materi dengan rata-rata skor sebesar 4,19; (2) Kategori sangat baik menurut ahli media dengan rata-rata skor sebesar 4,31; (3) Kategori baik menurut guru dengan rata-rata skor 4,23 dari skor ideal 5. Efektif dalam memfasilitasi pemahaman konsep siswa pada materi segitiga berdasarkan hasil post test bahwa sebesar 69\% siswa yang mengikuti post test memperoleh nilai lebih besar atau sama dengan KKM. Praktis berdasarkan respons siswa terhadap LKS Matematika berbasis pembelajaran kontekstual pada kategori baik dengan rata-rata keseluruhan 3,55 dari skor ideal 5. Oleh karena itu, LKS Matematika berbasis pembelajaran kontekstual untuk memfasilitasi kemampuan pemahaman konsep matematis siswa kelas VII SMP/MTs pada materi segitiga telah layak digunakan dalam pembelajaran. Hasil penelitian ini juga dapat memberikan kontribusi yang positif terhadap ilmu pendidikan pada umumnya dan khususnya untuk pelaksanaan pembelajaran matematika di kelas. Seperti siswa dapat melakukan pembelajaran secara menarik, meningkatkan kerja sama antarsiswa untuk memecahkan permasalahan, menghilangkan kejenuhan dalam belajar, dan meningkatkan prestasi. Bagi guru sendiri dapat mengembangkan inovasi perangkat pembelajaran dan proses pembelajaran tidak lagi berjalan secara monoton.

\section{DAFTAR PUSTAKA}

Afrilianto, M. (2012). Peningkatan pemahaman konsep dan kompetensi strategis matematis siswa SMP dengan pendekatan metaphorical thinking. Jurnal Infinity, 1 (2), 192-202. https://doi.org/10.22460/infinity.v1i2.p192-202

Arifah, U., \& Saefudin, A. A. (2017). Menumbuhkembangkan kemampuan pemahaman konsep matematika dengan menggunakan model pembelajaran guided discovery. UNION: Jurnal Pendidikan Matematika, 5 (3), 263-272. https://doi.org/10.30870/jppm.v10i2.2032

Artikasari, E. A., \& Saefudin, A. A. (2017). Menumbuhkembangkan kemampuan berpikir kreatif matematis dengan pendekatan contextual teaching and learning. Jurnal $\begin{array}{lllll}\text { Math Educator } & \text { Nusantara, } & 3 & \text { (2), } & \text { 73-82. }\end{array}$ https://doi.org/https://doi.org/10.29407/jmen.v3i2.800

Astuti, Y., \& Setiawan, B. (2013). Pengembangan lembar kerja siswa (LKS) berbasis pendekatan inkuiri terbimbing dalam pembelajaran kooperatif pada materi kalor.
Jurnal
Pendidikan
$I P A$
Indonesia,
2
(1).

https://doi.org/https://doi.org/10.15294/jpii.v2i1.2515 
Formatif: Jurnal Ilmiah Pendidikan MIPA

Vol. 9, No. 1, Maret 2019, pp. 1-10

p-ISSN: 2088-351X

e-ISSN: 2502-5457

DOI: http://dx.doi.org/10.30998/formatif.v9i1.2773

Gazali, R. Y. (2016). Pengembangan bahan ajar matematika untuk siswa SMP berdasarkan teori belajar ausubel. Jurnal Pendidikan Matematika Pythagoras, 11 (2), 182-192. https://journal.uny.ac.id/index.php/pythagoras/article/view/10644/pdf

Handayani, S. D. (2016). Pengaruh konsep diri dan kecemasan siswa terhadap pemahaman konsep matematika. Formatif: Jurnal Ilmiah Pendidikan MIPA, 6 (1), 23-34. DOI: http://dx.doi.org/10.30998/formatif.v6i1.749

Istikhomah, D. A., \& Jana, P. (2018). Kemampuan pemahaman konsep matematis mahasiswa melalui pendekatan pembelajaran saintifik dalam perkuliahan aljabar matrik. Prosiding Seminar Nasional Etnomatnesia, (pp. 927-932). Yogyakarta. http://jurnal.ustjogja.ac.id/index.php/etnomatnesia/article/view/2438

Jana, P. (2018). Penguatan kemampuan matematika dasar siswa SMA melalui kegiatan matrikulasi. MATAPPA: Jurnal Pengabdian Kepada Masyarakat, 1 (1), 1-4. https://doi.org/http://dx.doi.org/10.31100/matappa.v1i1.80

Karim, A. (2017). Analisis pendekatan pembelajaran CTL (contextual teaching and learning) di SMPN 2 Teluk Jambe Timur Karawang. Formatif: Jurnal Ilmiah $\begin{array}{llcc}\text { Pendidikan MIPA, } & 7 & \text { (2), } \\ \text { https://doi.org/http///dx doi.org/10 } & \text { 30998/formatif.v7i2 1578 }\end{array}$

Layn, M. R. (2018). Meningkatkan hasil belajar matematika melalui model pembelajaran kooperatif tipe NHT pada siswa kelas VIII A MTS Muhammadiyah Kota Sorong. Formatif: Jurnal Ilmiah Pendidikan MIPA, $8 \quad$ (1), 43-50. https://doi.org/http://dx.doi.org/10.30998/formatif.v8i1.2319

Puslitjaknov. (2008). Metode Penelitian Pengembangan. Jakarta: Departemen Pendidikan Nasional.

Rahayu, S., Rasna, I. W., \& Artawan, G. (2013). Penerapan model pembelajaran kontekstual dalam pembelajaran menulis pada siswa kelas XII SMKN 1 Denpasar. e-Journal Program Pascasarjana Universitas Pendidikan Ganesha, 2, 1-13. http://oldpasca.undiksha.ac.id/ejournal/index.php/jurnal_bahasa/article/view/583

Saraswati, A. M., \& Nuryani, C. E. (2018). Pengembangan lembar kegiatan siswa (LKS) berdasarkan model pembelajaran guided discovery. Jurnal Aksioma, 9 (1), 97-112. http://dx.doi.org/10.26877/aks.v9i1.2516

Suhana, C. (2014). Konsep Strategi Pembelajaran. Bandung: Refika Aditama.

Sungkono. (2009). Pengembangan Bahan Ajar. Yogyakarta: Universitas Negeri Yogyakarta.

Widoyoko, E. P. (2016). Hasil Pembelajaran di Sekolah. Yogyakarta: Pustaka Pelajar.

Yuliyani, R., \& Handayani, S. D. (2017). Peran efikasi diri (self efficacy) dan kemampuan berpikir positif terhadap kemampuan pemecahan masalah matematika. Formatif: Jurnal Ilmiah Pendidikan MIPA, 7 (2), 130-143. http://dx.doi.org/10.30998/formatif.v7i2.2228 
Formatif: Jurnal Ilmiah Pendidikan MIPA

Vol. 9, No. 1, Maret 2019, pp. 1-10

p-ISSN: 2088-351X

e-ISSN: 2502-5457

DOI: http://dx.doi.org/10.30998/formatif.v9i1.2773

Halaman ini disengaja kosong 